\title{
Conclusiones e ideas sobre el Estado del bienestar
}

\author{
Eva Ma Menéndez Sebastián \\ Profesora Titular de Derecho Administrativo. Universidad de Oviedo \\ menendezeva@uniovies
}

Welfare State anglosajón, État-providence francés, Socialstaat alemán, el Estado del bienestar en nuestro sistema, o incluso las políticas del New Deal de Franklin Roosevelt en Estados Unidos, son algunas de las denominaciones que se han venido dando para designar al Estado que legisla en materia social, en el sentido de aquél que a finales del S. XIX interviene y reacciona frente a las mutaciones sociales ligadas a la revolución industrial y que constituye una ruptura fundamental en la concepción del Estado hasta entonces imperante.

Un siglo más tarde, la mundialización y la fuerte crisis económica que asola no sólo a nuestro país sino a toda Europa, obliga a los poderes públicos a repensar las modalidades para hacerse cargo de los riesgos sociales.

Partiendo de los distintos modelos de Estado social practicados en diversos países de nuestro entorno, así como su nacimiento y evolución, tanto desde el prisma jurídico como histórico, sociológico y económico, es necesario analizar el papel de los juristas y de las diversas instituciones del Derecho en la consecución y mantenimiento del Estado social, así como la posibilidad de articular una nueva relación Estado-Sociedad para hacer frente a la crisis del mismo y cómo el Derecho y, particularmente, el Derecho Administrativo debe adaptarse a esas nuevas circunstancias y servir al citado objetivo.

Todo ello sin perder de vista el papel que en la situación actual han tenido las políticas europeas, que pivotan sobre el principio de libre competencia, así como las medidas adoptadas frente a la crisis desde la perspectiva del mantenimiento del euro y no del bienestar social.

Las políticas neoliberales europeas han venido a sustituir de facto los valores de igualdad, justicia, solidaridad de las Constituciones de los Estados contemporáneos de nuestro entorno y proclamados en el art. 1.1 de nuestra Carta Magna, por el principio de libre competencia y cómo ello hace tambalear el Estado social.

De otro lado, el Derecho Público, que juega un papel primordial en la articulación de las relaciones entre Estado y Sociedad, que ahora más que nunca deben reformularse y permitir al Estado recobrar su sitio, debe ser también repensado.

El Estado social se plantea como objetivo, como Estado garante del interés general -en el sentido de bien común de la sociedad de Tomás de Aquino y no como suma de intereses particulares propio de Adam Smith-, preservando una serie de derechos de los ciudadanos, y reformulando los medios para alcanzarlos, pues si el instrumento que fue a este respecto en sus orígenes el Estado prestacional, no sirve hoy para recomponerlo, habrá que acudir a nuevas fórmulas, como ha advertido Esteve Pardo.

No estamos sólo ante una crisis económica sino también institucional, pues es evidente que la evolución experimentada en los últimos tiempos ha provocado un desajuste entre el Estado y la Sociedad, de tal modo que el entramado institucional existente ha perdido sintonía con la nueva realidad social. Ante una situación como ésta, que aunque infrecuente no es la primera vez que se produce, recuérdese la crisis del antiguo régimen, los juristas debemos reaccionar también, junto a sociólogos, historiadores y economistas, en busca de una adecuada solución. Pues como señalara entonces Alexis Tocqueville muy acertadamente, la misma se debió a un desfase del régimen político, institucional y jurídico con la nueva sociedad que se había configurado.

Si entonces se crearon muchas de las instituciones hoy existente en nuestro ordenamiento, como respuesta, hoy -y si bien la historia no se repite pero a veces rima, como advirtiera el historiador Mark Twain-, debemos cuan- 
to menos repensar también el papel de esas instituciones al servicio del logro del bienestar y justicia social, que un Estado Social Democrático y de Derecho como el nuestro debe garantizar.

$Y$ es que no debe olvidarse que el Estado social es el mayor logro histórico y que permite además la convivencia, y que si en las circunstancias de crisis que vivimos no puede ofrecer los mejores servicios sanitarios, de educación, asistenciales, etc, al menos, debe ser igualitario y solidario. Pues de otro modo, como se está produciendo en la actualidad, se abre aún con mayor intensidad la brecha entre quienes disponen de mayores recursos y quienes se ven cada vez en mayor medida privados de servicios de calidad.

Pues como se proclamara ya en la importantísima Declaración de Filadelfia de 1944, un país no puede ser sostenible sin una justicia social. 